Conjunction in R.A. Oct. 12, 1605 , at oh. $3 \mathrm{Im}$. 445.G.M.T.

R.A. $\quad \ldots \quad \ldots . \quad \ldots \quad 197^{\circ} 4 \mathbf{I}^{\prime} \quad 5 \mathbf{I}^{\prime \prime}$

Moon's hourly motion in R.A. $\quad \ldots \quad \ldots \quad \ldots \quad 35 \quad 37$

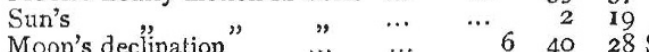

7 75 r $33 \mathrm{~S}$

Moon's bourly motion in Declination ... $\quad$ Io $50 \mathrm{~S}$.

Sun's " " $\quad, \quad \ldots \quad \ldots . \quad 0 \quad 56 \mathrm{~S}$.

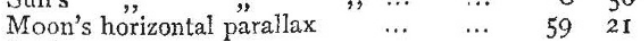

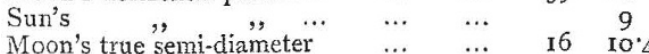

$\begin{array}{llllllr}\text { Sun's } \quad, \quad \ldots & \ldots & \ldots & \text { 16 } & 30^{\circ}\end{array}$

The sidereal time at Greenwich mean noon Oct. I2 was 13 h. $24 \mathrm{~m}$. 10'9s., and the equation of time r $3 \mathrm{~m} .29 \mathrm{~s}$. additive to mean time. The eclipse would be total and central with the sun on the meridian, in longitude $11^{\circ} 18^{\prime}$ W., and latitude $52^{\circ} 26^{\prime} \mathrm{N}$. For Naples, a direct calculation gives a total eclipse, the sun at an altitude of $31^{\circ}$. Beginning of totality at $2 \mathrm{~h}$. I $8 \mathrm{~m}$. I $8 \mathrm{~s}$, , ending at $2 \mathrm{~h}$. I gm. 28 s., mean time at Naples, or duration Im. IOs., which appears to correspond fairly with Kepler's statement that the sun was "covered for a short time" only.

The Minor Planets.-M. Stephan, Director of the Observatory at Marseilles, announces the discovery of another small planet by M. Borelly, on December $I$. Right ascension at midnight, $65^{\circ} 31^{\prime}$; north polar distance, $66^{\circ} 2^{\prime}$; motion towards north-east, thirteenth magnitude. Supposing ail the recently detected minor planets to be new, this will be No. 157. The last circular of the "Berliner Astronomisches Jahrbuch," however, has a suggestion by Prof. Tietjen that No. 152 , discovered by M. Paul Henry at Paris on November 2, may prove to be the same planet which was found by M. Borelly, 1868 , May 29, and which received the name Dike. No. 152 passed the ascending node soon after noon on November 3 , the geocentric longitude at the time being $41^{\circ} 54^{\prime}$, and it was not far from opposition, which is so far favourable to the supposition of identity with Dike, with ascending nore in $4 \mathrm{I}^{\circ} 5 \mathrm{O}^{\prime}$ according to the most probable orbit that could be obtained from the short course of observations in 1868 . Dike was estimated of thirteenth magnitude, yet in 1868 was observed within $10^{\circ}$ from perihelion; in ascending node the planet would be less than $29^{\circ}$ from aphelion ; No. 152 is called eleventh magnitude, a difference, considering the respective orbital positions, which is adverse to identity. The unfavourable weather has prevented observations sufficient for a proper calculation of elements for No. 152. Should this planet prove to be identical with No. 99 (Dike), the numbers from 153 onwards will of course require to be diminished by one, and the actual number of small planets, including $M$. Borelly's late discovery, will stand at 156 .

\section{THE MAMMALS OF YARKAND*}

${ }^{\top} \mathrm{HE}$ unfortunate death of the lamented naturalist, Stoliczka-one of the most promising members of the Indian Geological Survey - must be fresh in the memory of many of our readers. After a successful campaign in Yarkand in company with Sir D. Forsyth's late expedition, he did not live to return to India, but perished of exhaustion amongst the snows of the Himalayas. We are pleased to hear that his Indian friends have undertaken the preparation of a work intended as a memorial of him, which will embrace an account of the extensive collections of natural history amassed during his last journeys. Mr. W. T. Blanford has just issued a preparatory list of the mammals of which specimens were obtained in Yarkand and the adjoining countries. They are referable to forty-two species, mostly belonging to groups characteristic of the elevated districts of the Palæarctic

* "List of Mammalia collected by the late Dr. Stoliczka when attached to the Embassy under Sir D. Forsyth, in Kashmir, Ladák. Eastern Turkesta, and Wakhau, with descriptions of new species." By W. T. Blanford, F.R.S., F.Z.S. (Journ. As. Soc. Bengal, vol, xliv. D. To5, et seqq.) region. No new types were discovered, but amongst the novelties are species of Field-voles, Hares, and Pikas (Lagomys), all very distinctive of the regions traversed by the expedition, and adding largely to our knowledge of the fauna of Western Tibet and Eastern Turkestan. The larger mammals were originally better represented, but after Dr. Stoliczka's death, many specimens appear to have been removed from the collection. Of a fine series of twenty-two wild sheep from Kashgar, only eleven are now left, and not one of these has fine horns. Moreover there remain skeletons of wild sheep and ibex in the collection, of which the heads have entirely disappeared. Mr. Godwin Austen has invited public attention to these unpleasant facts in another column of this journal. One would have supposed that in the case of a naturalist thus perishing in the performance of his arduous duties, no pains could have been too great to protect the specimens in procuring which he had sacrificed his life. On the contrary, however, advantage appears to have been taken of his untimely death to rob his collection of the choicest specimens. We can orly trust that, attention having been called io the fact, restitution will be made, and the missing heads and Lorns promptly restored to the mutilated specimens now deposited in the Imperial Musenm at Calcutta.

\section{ARCHAEOLOGICAL RESEARCHES IN KEN. TUCKY AND INDIANA}

$N$ January last Mr. Putnam laid before the Society of 1 Natural History of Boston, U.S., an extended account of his recent archæological researches in Kentucky and Indiana, in which he had examined several rock-shelters, caves, mounds, and circular graves. He called attention to the numerous ancient fortifications in the Ohio valley, and gave a description of two which he had visited in Indiana. These fortifications are generally earthworks, many of them of great extent; but there have been several discovered in which immense walls of stone have been used, extending in one case to several hundred feet in length, and to nearly ten feet in height; whilst in another instance a wall about seventy-five feet in height had been erected to fill a gap in the otherwise nearly precipitous natural wall. The stones of these walls were simply laid, one overlapping another, so as to break joints, without cement of any kind. Mr. Putnam exhibited to the meeting a number of human skulls and other bones found under various conditions, and pointed out that while the skulls of the New England Indians were long and narrow and belonged to the dolichocephati, those from the mounds, the circular graves, the stone graves, and the caves were of the short, broad and high type, or the brachicephali. In the caves, however, there were two, if not three, classes of burials, and at least two wellmarked forms of skull. The skulls he found in graves protected with slabs of stone were all of a form very closely resembling the high, short and broad crania of the mound builders; those of the numerous skeletons from the caves were characterised by the marked depression of the frontal bone and the equally marked concavity on the anterior part of the parietals; and the skulls from the circular graves were distinguished from the others by their decided width and shortness, and the more vertical occipital portion.

A series of shin-bones was also exhibited to show the various degrees of flattening, and to confirm the opinion of Mr. Busk and others that platycnemism cannot be taken as an important race character.

Of a number of circular graves which formerly existed on a hill near Glasgow, one, having escaped the plough, had been carefully opened. It was a circle about four feet in diamêter, and had been dug to a depth of three feet, where a floor had been formed with pieces of shale brought from a distance of about a quarter of a mile 
Around the circumference were placed upright slabs of limestone three feet high, and at least ten bodies had been lodged in the grave, arranged in a sitting posture with their backs against the slabs, and the hole had then been filled up. The teeth showed that the majority were of middle age, whilst the remainder included old persons and children still retaining their milk teeth. The limestone slabs projected a few inches above the present surface of the soil, so that if the grave had ever been covered with an earth mound the latter must have been removed, perhaps washed away. The only artificial object found was one solitary potsherd; hence there is no evidence to prove or disprove any speculation which may be indulged respecting the people whose burial-ground had been thus laid open in the interest of science. It is perhaps safe to conclude that all the bodies found in the grave were placed there at one and the same time.

The Salt Cave, near the Mammoth Cave, and rivalling it in the size of some of its branches, was clifficult of access, on account of loose rocks which had fallen from the roof, and of a stream of falling water xunning off between them. Having effected an entrance, the descent of a steep hill of loose rock led into a large gallery several miles in length, the floor of which was covered with fallen rocks. Small areas were occasionally found, however, where no such masses piesented themselves, but where fires had been kindled, and where small piles of stones had been raised around a small central hole having ashes and remnants of burnt sticks at the bottom; whilst on the adjacent rocks there were in some cases found small bundles of sticks tied with bark, and of a convenient size to be placed in the holes, thus indicating that they had been brought into the cave to be used as lights and as firewood.

Further on, in a small chamber never previously visited by a white man, there were seen on the cave earth the imprints of feat shod with peculiar braided mocassins or sandals. In some of the side chambers were found a great number of cast-off sandals, very finely made of the twisted leaves of some rush braided in a careful and artistic way. The manner of braiding was identical with that of the straw sandals from China, but the form of the sandal itself was different. About twenty-five of these sandals, of various sizes and of slightly varying designs, but all worn through at toe and heel, were found in the interior chamber of the caye.

A piece of cloth more than a foot square, and finely and regularly woven, probably from the inner bark of some tree, was also found, and was especially interesting from having been dyed or coloured with black and white stripes, and from having in one place been mended by darning.

Mr. Putnam also exhibited bunches of the bark used to make the cloth, and of different degrees of fineness; a number of pieces of bark, twine, and rope, some made of twisted strands simply, whilst others were of a five-strand braid and of a more pliable substance; a small piece of quite a delicate fringe or tassel of neatly braided fibres ; a number of reed "torches," generally burnt at one end ; a few small fragments of burnt wood, one of them showing the rough cutting of a flint axe; several fragments of a large gourd, of a species probably not indigenous; two flint arrow-points; a few fragments of shells of the Unzo; and a few feathers of probably the wild turkey. All the specimens of cloth, \&c. from Salt Cave were extremely brittle, and had only been preserved by saturating them with gelatine and afterwards mounting between glass. No bones or other relics indicative of the food of the cave people were found, nor was there any evidence of human interment, though the earth in one of the chambers had been disturbed; the state of Mr. Putnam's health, how. ever, prevented him from making anything like an exhaustive examination. It is encouraging to know that it is intended to continue the work until more is ascer- tained of the archæology of this large group of important American caves.

The discovery, in $18: 2-15$, of bolies buried with care in some of the caves of Kentucky and Tennessee, and of the numerous articles found with them, was alluded to by Mr. Putnam, who stated that since his return from Kentucky he had examined the body, and what remained of the very large number of articles found with it, that was so widely known as the "Mammoth Cave Mummy" sixty years ago. This body, in reality found in Short Cave, had been taken to the Mammoth Cave, eight miles distant, for exhibition. The relics had been sadly neglected, and many of the articles found in the grave had been lost and others had gone to decay; still enough remained, at the rooms of the American Antiquarian Society at Worcester, to identify the articles found in Salt Cave as the same in material, clesign, and structure as those found with the body in Short Cave, so that he had thus secired undoubted osteological characters to go with the articles of clothing, \&c., of the Salt Cave people, and he thought that we could, with little doubt, class this people among the more highly civilised and agricultural of the prehistoric races of America.

\section{SCIENCE IN ITALY*}

UDGING from the number of scientific papers that we are in the habit of receiving from Italy, we are glad to infer that the restoration of political unity and freedom has also brought about a revival of that intellectual vigour which we are accustomed to associate with the names of Dante and Tasso, Galileo and Torricelli. When Italy was divided, and each State politically oppressed, her best men were in exile, and their best scientific work was expressed in a foreign tongue. Research was not only not encouraged, it was practically prohibited. It seems incredible, but it is nevertheloss true, that the Austrian and Bourbon Governments, in their dread of novelty, would not allow the results of modern research to be taught in the schools. The text-books reproduced the exploded science of the past, in which the modern theory of dew, for example, was ignored; so that Melloni (whose best work was done in Paris, and its results published in French journals), in making a series of observations on the nocturnal cooling of bodies in the neighbourhood of Naples, wished to show that the laws of terrestrial radiation were the same in Italy as in countries where there was more political liberty. We have it on the authority of Matteucci, that he and others, when they revisited their native land, were placed under the surveillance of the police, not from the fear of their meddling with politics, but on account of the scientific reputation which conferred distinction upon them.

Under such circumstances science could not flourish, and the time has perhaps been too short since Italy recovered her freedom to enable her to do much more than revive the glories of the past, and to seek encouragement in the example of the great men who have gone before. Hence it is that in the papers before us, points are discussed in connection with objects of Italian discovery, such as the electrophorus and the condenser, in which old names are curiously mingled with new. Thus Beccaria, Epinus, Priestley, Volta, and Avogadro are asso* "On Certain Principles of Electrostatics." A series of experiments. By Prof. G. Cautoni. "Su Alcuns Principj," \&c. (Milan, 1873.) - "On Certain Controverted Points in Electrostatics." Note by the same. (Milan, 1873.)-- "Important Observations of Beccaria on Electrical Condensers." By the same. Read before the Royal Society of Science and Literature of Lombardy, Feb. 20, 1873 - - "On the Polarisation of Electrics." By the same. Read December 4 and $18,1873 .-$ "On the Limits of Resistance in Electrics." By the sane. Read April 23, $1874 .-$ " Experiments in Electrostatics." Parts 1 and 2. By the same. Read June 25 and Dec. 24, I874."The Discoveries of Fusinieri; historical notes illustrated by an account of some of his instruments preserved in the Civil Museum of Vicenza." By G. Nardi. "Le Scoperte del Fusinieri," \&c. (Vicenza, 1875.)-"The Theory of the Combination of Gases by means of Solids, as elaborated by Fusinieri, in 1824," \&c. "By G. Nardi. Read before the Academie Olim pica, 19th_May, 1875. "La Teoria," \&c. (Vicenza, 1875.) 